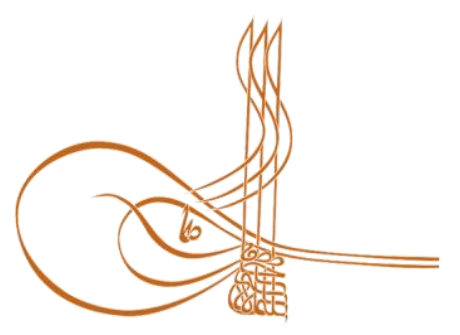

www.turkishstudies.net/turkishstudies
Turkish Studies

eISSN: $1308-2140$

Research Article / Araştırma Makalesi

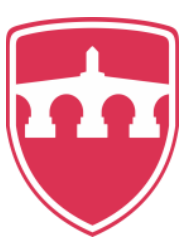

INTERNATIONAL

BALKAN

UNIVERSITY

Sponsored by IBU

\title{
Toplumsal Cinsiyet Eşitliği Temelinde Kadın Girişimciler \\ (Trabzon Örneği)
}

\author{
Women Enterpreneurs on the Basis of Gender Equality
}

(Trabzon Sample)

Mine Gözübüyük Tamer*

\begin{abstract}
In the labor market, it is clear that supporting women's initiatives and realizing their potential in this field is important for the sustainable development and welfare of our country. The aim of this study is to reveal the general appearance of women entrepreneurs (age, education, family history, etc.) and their entrepreneurship experiences (work experience, business/firm information, work-related equipment, gains, difficulties, supportive elements, goals and expectations) in Trabzon. The study is important in terms of exhibiting female entrepreneur experience in Trabzon. Because it makes it possible to make comparisons in order to reveal the differences or similarities with the results of other researches. The theoretical basis of the study is feminist economic theory because of including views on "division of labor as gender-based" and "attempting to create representation opportunities for these groups by enabling women to participate primarily in employment, education and politics". In-depth interview technique was used in the research within the qualitative research approach. The interviews were conducted with women entrepreneurs working in different business lines. In March-May 2018, face-to-face interviews were conducted with 14 women entrepreneurs operating in different sectors in Trabzon and the data of the interviews were evaluated with descriptive analysis. It is observed that the role of gender factor is effective in the sector selection for women entrepreneurs; It was found that the problems experienced in the process with the profile of women entrepreneurs support the literature. Recommendations have been made to include women in the labor market.
\end{abstract}

Structured Abstract: Turkey female population constitutes half of the population. Employment of such an important population for sustainable development is of great importance. Access to and participation in labor markets enables women to benefit from social and economic developments and strengthen their position. It is therefore desirable to increase the number of women in the labor market and consequently to increase the production capacity. However, the number of female entrepreneurs in Turkey is still less than half of men. It is important to increase this rate, increase production capacity and ensure gender equality. In particular, it

\footnotetext{
${ }^{*}$ Doç. Dr., Karadeniz Teknik Üniversitesi, Edebiyat Fakültesi, Sosyoloji Bölümü Assoc. Prof. Dr. Karadeniz Teknik University, Karadeniz Technical University ORCiD https://orcid.org/0000-0001-6362-7626 mgozubuyuk@hotmail.com

Cite as/ Atıf: Gözübüyük Tamer, M. (2020). Toplumsal cinsiyet eşitliği temelinde kadın girişimciler (Trabzon örneği), Turkish Studies, 15(1), 213-231. https://dx.doi.org/10.29228/TurkishStudies.40520

Received/Geliş: 11 January/Ocak 2020

Accepted/Kabul: 25 February/Şubat 2020

Copyright (C) MDE, Turkey
} 
should be remembered that supporting women's initiatives and making their potential in this field a reality is important for the sustainable development and welfare of our country.

Starting from this, the aim of the study is to give an overview of women entrepreneurs in Trabzon (age, education, family history, etc.) and to reveal entrepreneurship experiences (work experiences, business/firm information, work-related equipment, gains, difficulties, supportive elements, expectations and targets etc.). The study is important in terms of revealing female entrepreneur experience in Trabzon. Because it makes it possible to make comparisons in order to reveal the differences or similarities with the results of other researches. In addition, this study was planned and conducted in order to make useful suggestions to women entrepreneurs, potential entrepreneurs and institutions and organizations supporting women entrepreneurs by making use of the basic information obtained from the research results. The theoretical basis of the study is feminist economic theory because it includes views on "gender-based division of labor" and attempting "to create representation opportunities for these groups by enabling women to participate primarily in employment, education and politics”.

The research is based on a qualitative research approach; in this way, in-depth interview technique was used. Using a structured questionnaire, participants were asked to answer a predetermined set of questions. Attention was paid to the fact that the women entrepreneurs (participants) included in the research were from different sectors. Interviews were conducted between 45 minutes and one hour. In the research, 'snowball sampling' technique was preferred for reaching sampling. First of all, a female entrepreneur who was the director of a private school in Trabzon for more than 20 years was interviewed; other participants were reached through the ring of references. Within the scope of the interviews, women entrepreneurs engaged in different business lines were taken into consideration and 14 women entrepreneurs operating in different sectors in Trabzon were interviewed face-to-face in March-May 2018. The data obtained from the interview were subjected to descriptive analysis.

The women entrepreneurs participated in the study ranged from 30 to 57 years. Women entrepreneurs who have been working for many years are considering transferring the company they have founded, leaving it to their children or retiring, while others think that they do not have any plans such as separation and that the enterprise will not progress without them. It is effective in functions that require women to have a one-to-one relationship with people; financial and official affairs. As the education level of the female entrepreneur increases, the impact on the business functions increases. On the other hand; the effect of workers working with university graduates and women entrepreneurs on business functions is more than others. This situation can be interpreted as university graduates have a more democratic and participatory management approach. It is observed that the female entrepreneur who is raised in a liberal and modern environment is more effective in business functions than her counterparts who are raised in traditional and protective environments. In the past, women whose mothers were employed or who are currently employed are more effective in business functions than others. This can be interpreted as working mothers raise their children more confidently. In cases where the partner is a partner, the influence of the husband increases and the effect of the woman decreases. This explains that in the case of partnership, the husband is more decisive in decisions. It was found that most of the women had an impact on business functions, was in charge of the job, and worked with one of the workers and family members. A spouse or father is a person who provides more financing and helps with financial and official affairs. In addition, the research revealed that they needed to be brave. In order to become courageous individuals, it was seen that upbringing and parenting professions affect the perspective of life. The biggest factor in entrepreneurship is the fact that women are aware of what they can really achieve. In this process, it was recognized that their spouses and their families were always their greatest supporters.

In the context of feminist economic theory, it was observed that the role of gender-factor attitudes in the selection of sectors for women entrepreneurs. Because, the enterprises established by women in accordance with their social roles in food-dessert making, patisserie, cafe management, small-scale store management etc. has shown itself. Most of the companies have a very high financial burden. In addition to this, although the woman has distanced herself from her traditional roles when she works as a paid or unpaid family worker outside the home, she has often had to fulfill her continuing social roles with the new roles she has acquired. It has been observed that in the domestic roles of women, especially in the sector where they engage in maternity roles, the works are carried out together. In addition, the difficulties in capital acquisition, low education and traditional texture have emerged as factors that increase women's husband and family dependence. Finally, it was seen that some women did activities to improve themselves and some 
women did not try to improve themselves. It appears that women's participation in educational activities is often low and that they do not make an effort to improve themselves in their spare time. In order to cope with competition, the organization of women among themselves can provide great benefits in terms of exchange of information and ideas on problem solving. Women should be willing to develop their knowledge and skills. Information portals or platforms can be created in order to follow the developments in the sector closely. The gender-based division of labor, which prevents women from acquiring different skills and professions, is strengthened through family, educational institutions and the media. All public awareness programs should be organized to change this. For this purpose, educational institutions and media should be utilized.

Keywords: Gender, Entrepreneur, Female entrepreneur, Feminist economic theory.

Öz: İşgücü piyasasında, kadınların girişimlerini desteklemenin ve bu alandaki potansiyellerini gerçeğe dönüştürmenin ülkemizin sürdürülebilir kalkınması ve refahı açısından önemli olduğu açıktır. Bu çalışmanın amacı Trabzon'da kadın girişimcilerin genel görünümleri (yaş, eğitim, aile geçmişi vb.) ile girişimcilik deneyimlerini (iş tecrübeleri, işletme/firma bilgileri, işe ilişkin donanımları, kazanımları, karşılaştıkları zorluklar, destekleyici unsurlar, hedef ve beklentilerinin) ortaya koymaktır. Çalışma Trabzon özelinde kadın girişimci deneyimini sergilemesi bakımından önemlidir. Zira sonuçları itibariyle konuya ilişkin yapılan diğer araştırma sonuçlarıyla farklılıkları ya da benzerlikleri ortaya koymaya yönelik kıyaslama yapmaya olanak tanıması mümkün kılmaktadır. Çalışmanın kuramsal zemininde "toplumsal cinsiyet temelli işbölümü”, "kadınların başta istihdam, eğitim ve siyaset gibi alanlara katılımlarını sağlayarak, bu gruplara temsil imkânı yaratmayı çalışma” gibi birtakım eşitsizlikleri ortaya kaldırmaya yönelik görüşleri içerdiğinden dolayı feminist iktisat kuramı yer almaktadır. Nitel araştırma yöntemi içinde araştırmada derinlemesine görüşme tekniği kullanılmıştır. Görüşmelerin olanak dâhilinde farklı işkollarında uğraşan kadın girişimcilerle yapılmasına özen gösterilmiştir. 2018 yılı Mart-Mayıs aylarında, Trabzon ilinde farklı sektörlerde faaliyet gösteren 14 kadın girişimci ile yüz yüze görüşülmüş ve görüşme verileri betimsel analizle değerlendirilmiştir. Cinsiyet faktörünün oluşturduğu rol tutumlarının kadın girişimciler için sektör seçiminde etkili olduğu, daha mikro işletmelerde işe girişildiği; kadın girişimci profili ile süreçte yaşanan sorunların literatürü destekler mahiyette olduğu tespit edilmiştir. Kadınların iş gücü piyasasına dâhil edilmesine yönelik önerilerde bulunulmuştur.

Anahtar Kelimeler: Toplumsal Cinsiyet, Girişimci, Kadın girişimci, Feminist iktisadi kuram

\section{Giriş}

Türkiye nüfusunun \% 49,8'ini yani yarısını kadın nüfus oluşturmaktadır. Sürdürülebilir kalkınma için böylesi önemli bir nüfusun istihdama ve işgücü piyasalarına katılımları büyük önem taşımaktadır. İşgücü piyasalarına erişim ve katılım, kadının sosyal ve ekonomik gelişmelerden yararlanabilmesini ve konumunu güçlendirmesini sağlamaktadır. Bu yüzden işgücü piyasasındaki kadın sayısının arttırılması ve buna bağlı olarak üretim kapasitesinin arttırılması arzu edilen bir durumdur. Aşağıda yer alan grafikte (Grafik-1'de) yer alan bilgilerden hareketle Türkiye'de yıllar itibariyle kadın ve erkeklerin 'işgücüne katılım oranları', yer almaktadır. 1955'lerde kadınların işgücüne katılım oranı \% 72 iken, 1970'lerde \% 50’lere düşmüştür. 1995'li yıllardan 2014'li yıllara kadar da işgücüne katılım oranı erkeklerde \% 70-78, kadınlarda \% 25-30 aralığında seyretmeye devam etmiştir. 2018 yılına gelindiğinde kadınların işgücüne katılım oranı erkeklerde $\%$ 78,6 iken kadınlarda bu oran \% 38,3 olarak tespit edilmiştir. Bu haliyle kadınların işgücüne katılım oranının erkeklerin yarısı kadar olduğunu söylemek mümkündür. Bu durum Türkiye'de cinsiyet eşitliğini ve piyasanın etkinliğini önemli derecede etkileyecek biçimde negatif bir görünüm arz etmektedir (Gözübüyük Tamer, 2016:214).

\footnotetext{
${ }^{1}$ Türkiye İstatistik Kurumu (TÜIK) tarafından derlenen iş gücü istatistiklerinin sınıflandırılmasında kullanılan tanıma göre "iş gücüne katılım oranı", "iş gücünün kurumsal olmayan çalışma çağındaki nüfus içerisindeki” payıdır. Çalışma çağındaki nüfus kurumsal olmayan nüfus da yer alan “15 yaş ve daha üzeri yaştaki” bireylerden oluşmaktadır.
} 
Grafik-1: Türkiye’de 1955-2018 Yılları Arasında Kadın ve Erkek İşgücüne Katılım Oranları (\%)

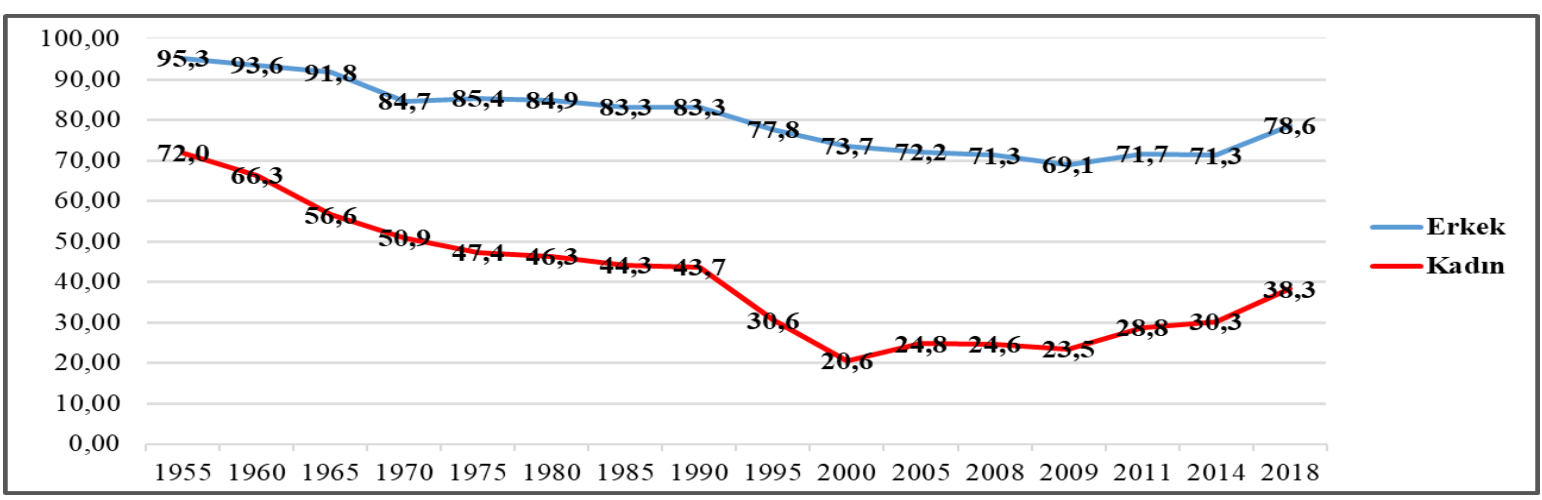

Kaynak: 1955-1995 yılları arası dönem Özer ve ark, 2004; 1995'den sonraki dönem Türkiye İstatistik Kurumu (TÜİK)'den alınan verilerle güncellenmiştir.

TÜIKK tarafından açıklanan hanehalkı işgücü araștırma sonuçları da (2018), bu durumu teyit emektedir. Buna göre, 2017 yılında, Türkiye'de 15 ve daha yukarı yaştaki istihdam edilenlerin oranı $\% 47,1$ olarak gerçekleşmiştir. $\mathrm{Bu}$ oran erkeklerde \% 65,6 iken kadınlarda \% 28,9 olarak belirlenmiştir. Bu arada, kadınların eğitim seviyesi yükseldikçe işgücüne daha fazla katıldıkları görülmüştür. Buna göre;

$>$ Okuryazar olmayan kadınların işgücüne katılım oranı \% 15,9

$>$ Lise altı eğitimli kadınların işgücüne katılım oranı $\% 27,7$

$>$ Lise mezunu kadınların işgücüne katılım oranı \% 34,3

> Mesleki veya teknik lise mezunu kadınların işgücüne katılım oranı \% 42,6

$>$ Yükseköğretim mezunu kadınların işgücüne katılım oranı \% 72,7'dir.

Diğer taraftan, istihdamın sektörel bazda dağılımına bakıldığında yıllar itibariyle kadınların tarım sektöründe istihdam edilme oranlarının düştüğü, buna karşılık hizmet sektöründe istihdam oranının yükseldiği görülür. 2018 yılı itibariyle kadınlar en fazla hizmet sektöründe istihdam edilmektedir (Tablo-1).

Tablo-1: Türkiye'de Kadın-Erkek İstihdamın Sektörlere Göre Dağılımı (\%)

\begin{tabular}{|c|c|c|c|c|c|c|c|c|c|}
\hline \multirow[b]{3}{*}{$\begin{array}{l}\text { Yil } \\
\text { Year }\end{array}$} & \multicolumn{9}{|c|}{ Ekonomik faaliyetler-Economic activities } \\
\hline & \multicolumn{3}{|c|}{ Tarım-Agriculture } & \multicolumn{3}{|c|}{ Sanayi-Industry } & \multicolumn{3}{|c|}{ Hizmet-Service } \\
\hline & $\begin{array}{c}\text { Toplam } \\
\text { Total }\end{array}$ & $\begin{array}{r}\text { Erkek } \\
\text { Male }\end{array}$ & $\begin{array}{r}\text { Kadın } \\
\text { Female }\end{array}$ & $\begin{array}{r}\text { Toplam } \\
\text { Total }\end{array}$ & $\begin{array}{c}\text { Erkek } \\
\text { Male }\end{array}$ & $\begin{array}{r}\text { Kadın } \\
\text { Female }\end{array}$ & $\begin{array}{r}\text { Toplam } \\
\text { Total }\end{array}$ & $\begin{array}{r}\text { Erkek } \\
\text { Male }\end{array}$ & $\begin{array}{r}\text { Kadın } \\
\text { Female }\end{array}$ \\
\hline 2007 & 23,5 & 16,8 & 42,7 & 26,7 & 30,4 & 16,1 & 49,8 & 52,8 & 41,2 \\
\hline 2008 & 23,7 & 17,1 & 42,1 & 26,8 & 30,8 & 15,7 & 49,5 & 52,1 & 42,3 \\
\hline 2009 & 24,6 & 18,1 & 41,6 & 25,3 & 29,1 & 15,3 & 50,1 & 52,7 & 43,1 \\
\hline 2010 & 25,2 & 18,3 & 42,4 & 26,2 & 30,3 & 15,9 & 48,6 & 51,4 & 41,7 \\
\hline 2011 & 25,5 & 18,7 & 42,2 & 26,5 & 31,1 & 15,2 & 48,1 & 50,3 & 42,6 \\
\hline 2012 & 24,6 & 18,4 & 39,3 & 26,0 & 30,7 & 14,9 & 49,4 & 50,9 & 45,8 \\
\hline 2013 & 23,6 & 17,8 & 37,0 & 26,4 & 31,1 & 15,3 & 50,0 & 51,0 & 47,7 \\
\hline 2014 & 21,1 & 16,1 & 32,9 & 27,9 & 32,4 & 17,1 & 51,0 & 51,5 & 50,0 \\
\hline 2015 & 20,6 & 15,9 & 31,4 & 27,2 & 32,0 & 16,2 & 52,2 & 52,1 & 52,5 \\
\hline 2016 & 19,5 & 15,5 & 28,7 & 26,8 & 31,6 & 15,9 & 53,7 & 53,0 & 55,4 \\
\hline 2017 & 19,4 & 15,4 & 28,3 & 26,5 & 31,4 & 15,6 & 54,1 & 53,2 & 56,1 \\
\hline 2018 & 18,4 & 14,9 & 26,1 & 26,7 & 31,6 & 16,0 & 54,9 & 53,5 & 57,9 \\
\hline
\end{tabular}

Kaynak: TÜIK, Hanehalkı İşü̈cü Araştırması, 2007-2018

2018 y1lında cinsiyete ve ekonomik faaliyetlere göre istihdam oranı incelendiğinde; ekonomik faaliyetler arasında tarım sektöründe istihdam edilenlerin oranı \% 19,4 olup erkek istihdam oranının \% 14,9, kadın istihdam oranının ise \% 26,1 olduğu görülmektedir. Sanayi sektöründe istihdam edilenlerin ekonomik faaliyetler arasındaki toplam oranı \% 26,7 olup bu 
sektörde istihdam edilen erkeklerin oranı \% 31,6; kadın istihdam oranı ise \% 16 olarak gerçekleşmiştir. Türkiye'de kadının işgücüne katılım ve istihdam edildiği sektörler değerlendirildiğinde, kadınların eğitim düzeyinin ve oranlarının düşük, çalışma yaşamına katılımının ise yetersiz olduğu görülmektedir.

İşgücüne katılan kadın girişimci oranına bakıldığında ise 2002 yılında \% 4 iken 2019 yılında \% 8,8'e yükseldiği görülür (KAGIDER, 2019:7). Yaklaşık son 20 yılda Türkiye'de kadın girişimci sayısındaki artış memnun edici olmakla birlikte, kadın nüfusa oranlandığında bu oranın çok düşük düzeyde kaldığı söylemek mümkündür. Uluslararası platformda da, girişimcilik aktivitesi açısından yoğun, iș firsatı yaratma beklentilerinin de yüksek olduğu bir ülke olan Türkiye, halen kadın girişimcilerin erkeklere oranla gerisinde kaldığı ülkelerden biri olarak konumlanmaktadır. Global Girişimcilik İzleme Raporuna göre Türkiye, kadın girişimcilerin erkeklerin yarısından az olduğu 48 ülke arasından Slovenya, Yunanistan, İsveç, Birleşik Krallık ve İsviçre'nin ardından 15. sırada yer almaktadır (KAGIDER, 2019:9). Bu yüzden gerek üretim kapasitesinin arttırılması gerek toplumsal cinsiyet eşitliğinin sağlanması açısından işgücüne katılan kadın girişimci oranının arttırılması gerekmektedir. Özellikle kadın girişimlerini desteklemenin ve bu alandaki potansiyellerini gerçeğe dönüştürmenin ülkemizin sürdürülebilir kalkınması ve refahı açısından önemli olduğu unutulmamalıdır.

Bu bağlamda, genelde girişimcilik özelde kadın girişimciliği konusunda gerek yurt dışında gerek yurt içinde farklı disiplinlerde araştırmalar sürdürülmektedir. Uluslararası ve ulusal yazın tarandığında bu konunun ne denli geniş bir yelpazede çalışıldığı görülür. Uluslararası yazında, girişimci kadınların özellikleri ve girişimci kadın tipi (Cromie ve Hayes 1988; Hisrich ve Grachev 1993; Romano 1994, Gupta ve Muita, 2013), girişimcilikte başarılı olmak için öngörülen şartlar (Hoy ve Shane 1998), girişimciliğe ya da işe başlamaya neden olan faktörler (Dhillon 1993), bu süreçte karşılaşılan sorunlar ve bu sorunların üstesinden nasıl gelindiği (Jick ve Mitz 1985; Abush ve Burkhead, 1984) gibi konular üzerine yoğunlaşılmaktadır. Ulusal ölçekte yapılan çalışma konularının da uluslararası alanda yapılan çalışmalara paralel olduğu görülür. Buna göre, meslek gruplarındaki girişimci kadınların karşılaştıkları sorunlar ve kültürel faktörler (Gürol, 2000; Çulcu, 2009, Sosyal, 2009; Demircioğlu, 2010, Cici 2013; Duman vd., 2015; Çetin vd., 2015; Kahraman, 2017, Avşar, 2017; Çelik, 2018), girişimci kadınların işyeri çevresinde ve aile içindeki ilişkileri (Çelebi 1993), girişimci özellikleri ve girişimcilik türleri (Kutanis, 2003; Kutanis ve Alpaslan 2006; Özkul ve Dulupçu, 2007; Öztürk, 2008; Mazgal 2013; Özgüner 2015), girişimci kadınların başarısı, güçlenme öyküleri ve girişimcilik fikirleri (Çakıcı, 2003; Varnalı, 2014; Örümcü, 2015; Mert, 2017), girişimciliğe ya da işe başlamaya neden olan, motive eden faktörler ile girişimcilik deneyimleri (Yağcı ve Bener, 2005; Demircioğlu, 2016) konusunda yapılan çalışmalar sıralanabilir. $\mathrm{Bu}$ çalışmaların genelde mikro düzeydeki çalışmalardan- bireyler, üniversite öğrencileri, işletme ve çalışan boyutlarına odaklı- oluştuğunu söylemek mümkündür. Buradan hareketle, kadın girişimcilerin özelliklerini, sorunlarını ortaya koyan çalışmalar bulunmakla birlikte; kadın girişimci sayısını artırmaya ve geliştirmeye yönelik araştırmalara ve projelere olan gereksinimin varlığı da devam etmektedir. Bu tarz araştırma ve projeler kadının iş hayatına çekilmesi bakımından teşvik edici olmakta ve farkındalık yaratmaktadır (Çelebi, 1993:12). Dolayısıyla erkek girişimcilerin yanında kadın girişimcilerin de işgücüne katılımını arttırmaya yönelik araştırmalara odaklanmak ülkemizde önemli bir faktör olarak karşımıza çıkmaktadır. Diğer taraftan, kadın özellikle de girişimci kadın bir ülkenin beşeri, sosyal ve ekonomik kalkınması için elzemse bu kadınlara yönelik araştırmalar yapılması, konuya dikkat çekilerek farkındalık yaratması ve başka kadınları bu yola sevk etmesi açısından önemlidir.

\section{Amaç}

Bu çalışmanın amacı, Trabzon'da kadın girişimcilerin genel görünümleri (yaş, eğitim, aile geçmişi vb.) ile girişimcilik deneyimlerini (iş tecrübeleri, işletme/firma bilgileri, işe ilişkin donanımları, kazanımları, karşılaştıkları zorluklar, destekleyici unsurlar, hedef ve beklentileri vb.) 
ortaya koymaktır. Çalışma Trabzon özelinde kadın girişimci deneyimini sergilemesi bakımından önemlidir. Zira sonuçları itibariyle konuya ilişkin yapılan diğer araştırma sonuçlarıyla farklılıkları ya da benzerlikleri ortaya koymaya yönelik kıyaslama yapmaya olanak tanımasını mümkün kılmaktadır. Ayrıca, bu çalışma araştırma sonuçlarına göre elde edilen temel bilgilerden yararlanarak kadın girişimcilere, potansiyel girişimcilere, kadın girişimcileri destekleyen kurum ve kuruluşlara yararlı olabilecek önerilerde bulunabilmek amaciyla planlanmış ve yürütülmüsstür.

\section{Yöntem}

Yorumlayıcı sosyal bilim anlayışı içinde yer alan nitel araştırma yöntemine dayalı bu çalışma, olgubilim (fenomenoloji) araştırma desenine uygun olarak kurgulanmıştır. Olgubilim deseni farkında olduğumuz ancak derinlemesine ve ayrıntılı bir anlayışa sahip olmadığımız olgulara odaklanmaktadır. Olgubilim araştırmalarında veri kaynakları araştırmanın odağında olguyu yaşayan ve bu olguyu dışa vurabilecek veya yansıtabilecek bireyler ya da gruplardır (Yıldırım ve Şimşek, 2016: 71). Bu araştırmalarda başlıca veri toplama aracı görüşme tekniğidir. Olgulara ilişkin yaşantıları ve anlamları ortaya çıkarmak için görüşmenin araştırmacılara sunduğu etkileşim, esneklik ve sondalar yoluyla irdeleme özelliklerinin kullanılması gerekmektedir. Aynı zamanda başkalarını anlamak için kullanılan en güçlü tekniklerdendir (Punch, 2005:34). Bu minvalde araştırmada yapılandırılmış soru formu üzerinden derinlemesine görüşme tekniği kullanılmıştır. Bu türde katılımcılardan önceden belirlenmiş bir dizi soruyu yanıtlaması istenmiştir. Görüşme, aynı zamanda standartlaştırıldığı için bütün yanıtlayıcılara, tüm sorular, aynı sırada ve standartlaştırılmış bir biçimde yöneltilmiştir. Görüşmeler 45 dakika ile bir saat aralığında gerçekleşmiştir.

Araştırmanın evrenini belirleyebilmek amacıyla Trabzon'da ilgili iki kuruluştan kadın girişimci sayısı talep edilmiş̧ir. İlk kurumdan gelen yazıda kadın girişimci sayısı 68 olarak belirtilmiş ancak iletişim bilgileri verilmemiştir; ikinci kurumdan gelen listede ise 356 kadın girişimcinin bilgilerinin (adı, soyadı ve firma bilgileri) yer aldığı görülmüştür. 356 kadın girişimcinin yer aldığı liste incelenmiş; adresi bulunmayan 81 işyerine rastlanmıştır. Bunun yanı sıra bazı firmalarında kadınlar adına açılmış olduğu görünse de işletmeciliğini eşleri ya da akrabalarının yaptığı tespit edilmiştir. Sağlıklı ve istenilen bir listenin temin edilemeyişinden dolayı örnekleme ulaşma konusunda 'kartopu' tekniği kullanılmıştır. Bu teknikle öncelikle Trabzon'da tanınan bir kadın girişimci üzerinden "bu konuyla ilgili kimlerle görüşmemizi önerirsiniz?" sorusu üzerinden tanıdığı bir başka kadın girişimciye ait iletişim bilgileri alınmış ve referans zinciriyle diğer katılımcılara ulaşılmıştır. Görüşmelerin olanak dâhilinde farklı işkollarında uğraşan kadın girişimcilerle yapılmasına özen gösterilmiştir. Özetle, 2018 yılı Mart-Mayıs aylarında, Trabzon ilinde farklı sektörlerde faaliyet gösteren 14 kadın girişimci ile iş yerlerinde yüz yüze görüşülmüştür.

\section{Araştırmanın Veri Toplama ve Değerlendirme Teknikleri}

Araştırmada veri toplama aracı olarak yapılandırılmış bir soru formu kullanılmıştır. Soru formu üç ana bölümden oluşmaktadır. Buna göre: İlk bölüm, kadınların kişisel özelliklerini tespit etmeye yönelik sorulardan oluşmaktadır. Bu sorular yaş, mesleki kıdem, medeni durum, çocuk sayıs1, eğitim düzeyi, sahip olduğu aile ve yetiştiği aile geçmişi, girişimciliğe aile yaklaşımı gibi alt başlıkları içermektedir. İkinci bölümde yer alan sorular iş deneyimi ile alakalıdır. Öncelikle kadınların girişimcilik algısı -girişimci olmanın ne demek olduğu, girişimci kadınlarda bulunması gereken özellikler neler olduğu vb.- sorgulanmıştır. Ardından girişimcilik serüveninin nasıl başladığ1, süreçte karşılaştığı sorunlar, hangi amaçlarla yola çıktığı, işe gitme süresi sıklığ1 gibi sorular yöneltilmiştir. Üçüncü bölümde yer alan sorular işletmeyle alakalıdır. İşletmenin kuruluş tarihçesi, hangi sektörde çalışıldığ 1 , işletme büyüklüğü, gelir durumu gibi sorular bu bölümde yer almaktadır. Son olarak geleceğe yönelik hedef ve beklentilerinin neler olduğunu belirlemeye yönelik bir soru yer almaktadır. Bu sorular çerçevesinde gerçekleşen görüşme kayıtları katılımcıların izni doğrultusunda kaydedilmiş, kaydedilen veriler daha sonra bilgisayar ortamında 
yazıya aktarılmıştır. Kayıtların deşifre edilmesi ana sorular ekseninde şekillenen alt başlıklar nezdinde gerçekleşmiş ve bu yolla veriler betimsel analize tabi tutulmuştur.

\section{Kuramsal ve Kavramsal Çerçeve}

Bu başlık altında toplumsal cinsiyet, girişimci, girişimcilik ve kadın girişimci olmak üzere dört temel kavram tanımlanmıştır. Ardından Feminist İktisat kuramına açıklık getirilmiş ve sonuçlar bu kurama yaslanılarak değerlendirilmiştir.

Toplumsal Cinsiyet, Batı'da geliştirilen ve feminist yaklaşımın en önemli analiz aracı olan "toplumsal cinsiyet" kavramı, sosyo-psikolojik ve kültürel olanı vurgulamak ve biyolojik olandan ayırmak üzere kullanılmakta (Başak, 2013); "sosyal yönden kadın ve erkeğe değişik kültürlerde verilen roller" olarak tanımlanmaktadır. Toplumsal cinsiyet, kadınlık ve erkekliğin biyolojik bir temeli kabulüne dayanmakla birlikte cinsiyetin, bu temelden ibaret olmadığı, onun üzerine kurulan ve toplumsal bağlama göre değişen bir örüntünün var olduğu tezine dayanır. Dolayısıyla, kadın ve erkeklerin farklılaşmaları biyolojik özelliklerinin olduğu kadar içinde yaşadıkları toplumun/sosyokültürel sistemin de bir sonucu olarak tezahür edebilmekte, biyolojik bir ayrımla kadın ya da erkek olarak doğan insanlar, cinsiyete dayalı rollerini yetişme sırasında öğrenmektedirler (Gözübüyük Tamer, 2018:670).

Girişimci kelimesi köken olarak 13.yüzyıl Fransızcasında kullanılan bir fiil olan "entreprende" den gelmekte olup, "bir şey yapmak" veya "üstlenmek" anlamına gelmektedir. Avusturyalı iktisatçı Joseph A. Schumpeter tarafindan, girişimcinin özünde bilindik çalışma kalıplarından sıyrılıp yeni bir tarz oluşturarak çalışmasını sürdürdüğü belirtilmiş ve girişimciyi, inovasyon yapan ve denenmiş teknolojileri geliştiren kişi olarak tanımlamıştır. Bununla birlikte Türk Dil Kurumu sözlüğünde girişimci kavramı; 1) Üretim için bir işe girişen, kalkışan kimse, müteşebbis; 2) Ticaret, endüstri vb. alanlarda sermaye koyarak girişimde bulunan kimse, müteşebbis, olarak tanımlanmaktadır. Bu tanımlardan hareketle, girişimciyi ticaret, sanayi gibi alanlarda sermaye koyarak bir işi yapmaya girişen, kâr amacıyla riski üzerine alan ve bilindik çalışma kalıplardan sıyrılıp yeni bir tarz oluşturarak çalışmasını sürdüren kişi olarak tanımlamak mümkündür.

Girişimcilik kavramı ise 1700'lü yılardan itibaren akademisyenlerin ilgi alanına girmiştir. Günümüze kadar farklı bilim dalları -iktisat, sosyoloji, psikoloji ve işletme vb.- konuyu farklı bakış açılarıyla ele almıştır. Kruger, "Girişimcilik Teorisi ve Yaratıcılık” başlıklı çalışmasında (2004), sosyal bilimlerde girişimciliğin dört farklı boyutta ele alınabileceğini belirtmiştir (tablo-2). Tarihsel süreçte ele alındığında girişimcilik kavramı ilk olarak iktisat yazınında ele alınmış ve gelişmiştir. Devamında psikoloji ve sosyoloji alanlarında davranışsal ve kültürel boyutuyla irdelenmiş ve daha yakın dönemde işletmecilerin sürdürülebilirlik, büyüme, verimlik ve post modern yönetim yaklaşımlarının vazgeçilmez bir unsuru olarak işletme yazınında ele alınmıştır.

Tablo-2: Girişimcilik Araştırmalarında Ana Görüşler

\begin{tabular}{|l|l|l|}
\hline Ana Akımlar & Araştırma Konuları & Soru Kısmı \\
\hline $\begin{array}{l}\text { Psikolojik: } \\
\text { Özellikler ve Davranışlar }\end{array}$ & $\begin{array}{l}\text { Girişimcilerin kişilik özellikleri ve } \\
\text { girişimcilik süreci }\end{array}$ & Nedenler (Neden) \\
\hline $\begin{array}{l}\text { Sosyolojik: } \\
\text { Sosyal ve Kültürel }\end{array}$ & $\begin{array}{l}\text { Farklı sosyal ve kültürel geçmişten gelen } \\
\text { girişimciler }\end{array}$ & Nedenler (Neden) \\
\hline Ekonomik & $\begin{array}{l}\text { Ekonomik çevre ve girişimcilik arasındaki } \\
\text { ilişki }\end{array}$ & Etkiler (Nelerdir) \\
\hline İşletme & Girişimci becerileri, yönetim ve büyüme & Davranış tarzı (Nasıl) \\
\hline
\end{tabular}

Pazar ekonomilerinin en önemli unsurlarından biri olan girişimcilik teorisine en büyük katkıda bulunan Joseph Schumpeter, girişimcinin merkezî rol oynadığı bir ekonomik gelişme 
teorisi ortaya koyarak ekonomik büyümenin sermaye birikiminden değil yeniliklerden meydana geldiğini ileri sürmüştür. Ona göre, yenilik ekonomik büyüme açısından hayati bir öneme sahipken, yeniliği gerçekleştirecek kişi de bireysel girişimcidir. Ancak bu çalışmanın katılımcılarının klasik yaklaşımın risk alan ve yenilik yapan girişimcisi olmaktan uzak olduklarını ifade etmek gerekir. Çalışmanın hedef kitlesini oluşturan kadınlar daha ziyade işgücü piyasasında kendine yer bulamadığı için başlangıç itibariyle büyük sermayeler gerektirmeyen alanlarda kendi işlerini kuran kadınlardır. Bu kadınlar klasik girişimci tanımına uymamakla beraber, destekleme mekanizmaları açısından girişimci olarak değerlendirilmiştir.

Genel bir tanımla "kadını girişimci "ev dışı bir mekânda, kendi adına kurduğu bir (veya birkaç) işyeri olan, bu işyerinde tek başına veya istihdam ettiği diğer kişilerle birlikte çalışan ve/veya işin sahibi olması sıfatıyla ortaklık kuran, herhangi bir mal veya servisin üretilmesiyle ilgili faaliyetleri yürüten, bu mal veya servisin dağıtım, pazarlama ve satışını yapan/yaptıran, işi ile ilgili olarak ilişkiye girmesi gereken kişi, örgüt, kurum ve kuruluşlarla kendi adına ilişki kuran, iş sürecinin örgütlenmesi, mal ve hizmet üretiminin planlanması, iş yerinin işletilmesi, kapatılması veya işin geliştirilmesi konusunda kendisi karar veren, işinden elde ettiği kazancı yatırım ve kullanım alanları üzerinde söz sahibi olan kadın" (Ecevit, 1993: 20) şeklinde tanımlanabilir. Ecevit'in bu tanımını sadeleştirecek olursak kadın girişimci, evinin dışında, üretim, satış, hizmet veya danışmanlık amaçlı bir işyerini kendisi kuran veya bir şekilde ortak olan ve fiili olarak işi idare eden kadınlar şeklinde tanımlanabilir.

\section{Kuramsal Çerçeve: Feminist İktisat Kuramı}

Türkiye'de kadınların iş gücüne katılma oranı yıllar itibariyle artan bir seyir izlemiş olsa da erkeklerle karşılaştırıldığında, erkeklerin iş gücüne katılma oranının gerisinde seyrettiği görülmüştür. Cumhuriyetin ilk yıllarından itibaren kadın iş gücü ve istihdamı, kadın girişimci sayısının arttırılması çözümlenmesi gereken bir sorun olarak görülmektedir. Bu noktada feminist iktisat kuramı, "toplumsal cinsiyet temelli işbölümü", "başta istihdam, eğitim ve siyaset gibi alanlara kadınların katılımlarını sağlayarak, bu alanlarda temsil imkânı yaratmaya çalışması" gibi birtakım eşitsizlikleri ortaya kaldırmaya yönelik görüşleri içerdiğinden dolayı çalışmada kullanılmıştır.

1960'll y1llarda ikinci dalga feminist hareketin de etkisi ile ilgili literatür içinde kendine yer bulmaya başlayan feminist iktisat, bu tarihten itibaren özellikle kadınların işgücüne katılımı, ev içi üretim, bakım emeği, işgücü piyasasında karşılaşılan ayrımcılık gibi konular etrafında yavaş yavaş şekillenmiştir. Strober'e göre (1994) bu yıllarda özellikle kadınların kamusal alanda karşılaştıkları ayrımcılık gündemde tutulurken feminist kuram ile paralel bir biçimde ataerki tartışmaları da iktisat disiplini içinde kendine yer bulmaya başlamıştır. Dolayısıyla, feminist iktisat yalnızca kadınların iktisadi konumlarının analiz edildiği bir iktisadi yaklaşım olmaktan ziyade kadınların dezavantajlı konumlarının iyileştirilmesi amacıyla kadın bakış açısının ve dolayısıyla kadınlara özgü bilme biçimlerinin, araştırma yöntemlerinin ve faaliyetlerin de kapsam içine alındığı ve cinsiyetçi yanlılıkların bertaraf edilmesinin amaçlandığı bir iktisat yaklaşımıdır.

Feminist iktisatçılar, temelde ekonominin kadınları nasıl etkilediği ve kadınların ekonomiyi nasıl etkilediği ile ilgilenmişlerdir. Kadınların ve erkeklerin ekonomide bulundukları konumun farklılığını korumaya devam etmesi, kadınların çoğunlukla ücretli işgücünün daha düşük bir bölümünü oluşturmaları, daha düşük gelir elde etmeleri, daha düşük statülerde istihdamları, evde gerçekleştirilen yaşl1lara, çocuklara bakım, ev içi temizlik vb. ücretsiz faaliyetlerde daha büyük rollerinin olması, kadına atfedilen ev içi sorumluluklarının ağırlı̆̆ı, kadınların erkeklere göre ekonomik açıdan dezavantajlı duruma geçmesine neden olmaktadır (Orkunoğlu ve Şahin, 2017: 444). Bu nedenle feminist iktisatçıların çoğu, çocukların bakımı konusunu ve kadınların ev içi ücretsiz faaliyetlerinin ölçümü konusunu incelemişlerdir. 
$\mathrm{Bu}$ çerçevede, bu yaklaşım, ana akım iktisadın (Neoklasik, Keynesyen, Marksist vb.), feminist bakış açısından bilim kuramına dayanan köklü bir eleştirisi veya çeşitli teorik yaklaşımlarla var olan iktisadın yerine getirilen farklı bir iktisat önerisi (Eroğlu ve İşler, 2004: 56) sunmaktadır. Klasik iktisadi düşüncede kadına biçilen rol kadınların, ana akım iktisadın en küçük ekonomik birim diye tanımladığı hanehalkı/ev içerisinde konumlandırılış biçimi, feminist iktisatçılarca, iktisada yaklaşımın eril merkezli olduğunun kanıtı niteliğindedir. Öyle ki klasik iktisadın büyük temsilcisi Adam Smith, "Ahlaki Duygular Kuramı" isimli eserinde kadınların en yüce faziletlerini namuslu ve alçakgönüllü olmalarına bağlamış, kadınların, eşlerine karşı saygılı, dikkatli, sadakatli olmalan gerektiğini bunlara ek olarak eşlerini sevmelerini ve onlara itaat etmeleri gerektiğini belirtmiştir. Smith tarafından kadına biçilen iktisadi rol aile içinde sınırlı kalmış, kadının kamusal alana dâhil edilmesi yersiz görülmüştür.

$\mathrm{Bu}$ minvalde, feminist iktisatçılar, ana akım iktisat metodolojisinin de eril bir yapıya sahip olduğunu, hâkim görüş olarak pozitivist bir bilim olan iktisadın nesnellik ve evrensellik olgularını içererek öznellik ve yerelliği dışladığını vurgular. Aynı zamanda kadınların iktisadi faaliyetlere katılımları, "ekonomik" ve "toplumsal" kalkınmadan faydalanma seviyeleri nüfuslarıyla doğru orantıda olmamaktadır. Bu ise ülkelerin gelişmişlik düzeylerine bağlı olduğu görülse de kadınlar bütün toplumlarda erkeklerden geride kalmıştır. Kadınların birçok anlamda erkeklerden geri kalmalarında bazı sebepler bulunmaktadır. Bu sebepler ataerkil kültüre yönelik toplumsal cinsiyet eşitsizliği, kadınların eğitim imkânlarından daha düşük seviyede faydalanması, kadınların erkeklerden fiziksel anlamda farklı olması, yasal düzenlemelerde yapılan yanlışlıklar ve eksiklikler olarak ifade edilmektedir. Dolayısıyla bu sebepler toplumların yapısal özellikleriyle yakından ilişkili olmaktadır (Yalınkaya, 2018:2). Hâlbuki kadınlar, sürdürülebilir kalkınmanın gerçekleştirilmesinde ve yoksulluğun azaltılmasında önemli bir unsur olarak görülmektedir. Bu da kadınların toplumsal ve ekonomik kalkınma sürecine faal olarak katılması, kadınların iş gücüne katılımının arttırılmasıyla gerçekleşecektir. Kısaca, iktisattan çok feminizmden doğduğu savunulan feminist iktisat, toplumsal cinsiyet eşitliğini/eşitsizliğini iktisat cephesinden yaklaşan bir bireşim (sentez) sosyal bilim disiplini olarak karşımıza çıkmaktadır. Bu disiplin, iktisadi yaşamda kadını değil, kadın bakış açısını da kapsamak ve böylece erkek kadar kadının da görünürlüğüne, farkındalığına ve temsiliyetine dayalı olmak üzere iktisadı incelemeyi amaçlar (Kalaycı, 2017:535).

\section{Bulgular}

$\mathrm{Bu}$ başlık altında araştırma sürecinde elde edilen verilerin analizi yer almaktadır. Araştırmaya dair bulguların aktarılması iki kısımdan oluşmaktadır: Birinci kısımda kadın girişimcilerin (katılımcıların) sosyo-demografik özellikleri; ikinci kısımda ise katılımcıların girişimcilik deneyimleri (iş tecrübeleri, girişimcilik algısı, işletme/firma bilgileri, işe ilişkin donanımları, kazanımları, karşılaştıkları zorluklar, destekleyici unsurlar, hedef ve beklentileri vb.) yer almaktadır. Bu kapsamda elde edilen bulgular, mülakatlarda sorulan sorulara paralel olarak tematik başlıklar halinde sunulmuştur. Görüşmeler metin içerisinde aktarılırken kadınları belirtmek açısından cinsiyet, yaş, çalıştığı sektör/işi göz önüne alınarak cümle sonlarına "K40yaşkonfeksiyon" gibi kısaltmalar konmuştur.

\section{I- Katılımcıların Sosyo-Demografik Görünümü}

Araştırmaya katılan kadın girişimciler 30-57 yaş aralığındadır. Katılımcıların eğitim düzeyi yüksektir. Altısı üniversite, dördü lise, ikisi lisansüstü ve ikisi de yüksekokul mezunudur. Evli kadın girişimcilerin sayısı (10) bekâr girişimcilerin sayısından (2) yüksektir. Katılımcıların ikisi hariç diğerleri evlidir. Evli olan kadınların genelde iki çocuk sahibi olduğu görülmüştür. Katılımcılardan biri üç çocuk, dördü tek çocuk, yedisi de iki çocuk sahibidir. Girişimci olarak kurdukları işlerde ortalama çalışma süresi 18 yıl olarak tespit edilmiştir. En az 6, en fazla 21 yıl iş deneyimine sahip kadın girişimciler araştırmada yer almıştır. 
Tablo-3: Katılımcıların Sosyo-Demografik Görünümleri

\begin{tabular}{|c|c|c|}
\hline \multicolumn{2}{|l|}{ Kategoriler } & \multirow{2}{*}{\begin{tabular}{|l|} 
Sayl \\
14 \\
\end{tabular}} \\
\hline Cinsiyet & Kadın & \\
\hline \multirow{2}{*}{ Medeni durum } & Evli & 12 \\
\hline & Bekâr & 2 \\
\hline \multicolumn{2}{|l|}{ Yaş Ort. } & 42 \\
\hline & En küçük yaş & 30 \\
\hline & En büyük yaş & 57 \\
\hline \multicolumn{3}{|l|}{ Eğitim Düzeyi } \\
\hline & Lise Mezunu & 4 \\
\hline & Yüksekokul mezunu & 2 \\
\hline & Üniversite Mezunu & 6 \\
\hline & Yüksek Lisans & 2 \\
\hline \multicolumn{2}{|c|}{ Çocuk sayısı Ort. } & 2 \\
\hline \multicolumn{2}{|c|}{ Çalışılan y1l/mesleki süre Ort. } & 18 \\
\hline & Min. & 6 \\
\hline & Max. & 21 \\
\hline \multicolumn{3}{|c|}{ Çalışılan Alan/Sektör } \\
\hline & Ev yemekleri-Pastane- üretim-satış & 3 \\
\hline & Eğitim Sektörü-Yöneticilik & 2 \\
\hline & Güzellik Salonu İşletmecisi & 2 \\
\hline & Konfeksiyon-Satış Mağazası & 3 \\
\hline & İç Mimarlık-El Sanatları & 2 \\
\hline & Mobilya-Ahize Satış Mağazası & 2 \\
\hline
\end{tabular}

Görüşülen kadın girişimcilerin büyük bir kısmının Ecevit (1993) tarafından ortaya konan girişimci kadın özelliklerine sahip olduğu, başka bir deyişle, ev dışı bir mekânda kendi adına kurduğu bir işyeri olan; bu işyerinde tek başına veya istihdam ettiği diğer kişilerle çalışan veya işinin sahibi olması sıfatıyla ortaklık kuran; herhangi bir mal veya hizmetin üretilmesi ile ilgili faaliyetleri yürüten, bu mal veya hizmetin dağıtım, pazarlama ve satışını yapan veya yaptıran; işle ile ilgili olarak ilişkiye girmesi gereken kişi, örgüt, kurum ve kuruluşlarla kendi adına ilişki kuran, işyerinin işletilmesi, kapatılması veya işin geliştirilmesi konusunda kendisi karar veren ve işinden elde ettiği kazancın yatırım ve kullanım alanları üzerinde söz sahibi olan kadınlardan oluştuğu tespit edilmiştir.

Eğitim geçmişinin girişimcilik üzerinde etkisi olup olmadığı konusunda katılımcılara bir soru yöneltilmiş olup alınan cevaplar, eğitim düzeyi ile girişimcilik arasında olumlu bir ilişkiyi gözler önüne sermektedir. Eğitim ile işlerin daha sistematik ilerlediği ve insanın farklı bir bakış açısı kazandığı ifade edilmiştir. Katılımcılar eğitim ve dolayısıyla bilgi ile ilerlemek gerektiğine inanmaktadırlar. Yapılan işin bilinçli olması gerektiği bunun içinde eğitimin şart olduğu vurgulanmıştır. Şuan yaptıkları iş alanında eğitim almamış girişimci kadınlar ise eğitimin bir etkisinin olmadığını düşünmektedirler. Başka bir deyişle, sektöre göre eğitime yapılan vurgunun da değiştiği gözlenmiştir. Eğitim olmadan da bu işin yapılabileceğini söyleyen bir katılımc1 ne olursa olsun "eğitimli insan bir adım önde olduğunu” vurgulamaktadır (K52yaş-yemek/tatl1). Bir başka kadın girişimci eğitimin mutlaka olumlu etkisi olduğuna dikkat çekerek "iş yapabileceğiniz alan ile ilgili bilgilenmiş olursunuz, mesela başlangıçta yapacağınız iş hakkında karar verip o konuda 
eğitim alırsanız olumlu etkiler görürsünüz" sözleriyle eğitimin önemini ön plana çıkarmıştır (K55 yaş-Okul müdürü).

Bireylerde girişimcilik olgusunun ortaya çıkmasını etkileyen faktörlerden biri de çevresi/ailesi olmuştur. Anne-baba meslekleri, sosyal statüleri, yetiştirme tarzları, ailenin değer yönetimi, çocuk sayısı gibi unsurlar ailenin etkilerini oluşturmaktadır. Ailenin çocuklarının girişimcilik niyetlerinde ki etkisini araştırmacılarda bazıları ise iki nedenle açıklayabilmektedir; rol model olma ve aile desteği. Ailesi girişimci olan çocukların ileride kendi işletmelerini kurması ihtimali yüksektir. Kendisine ait bir işte çalışan girişimci ebeveynin çocuğunun da benzer eğilimler göstermesi yapılan birçok araştırmada karşılaşılan bir gerçektir. Bu rol model etkisidir. Aile desteği ise; ailenin bu yolda bireye finansal ve manevi yönden destek vermesidir (Cici 2013). Bu çerçevede, kadınlara nasıl bir aileden geldikleri, ailelerinde başka girişimciler olup olmadığı ve varsa eğer bu kişilerden ne yönde etkilendiklerine dair sorular yöneltilmiştir. Kadın girişimcilerden altısı modern (gelenekleri sorgulayan) ve dördü de geleneksel bir ortamda yetiştiklerini ifade etmişlerdir. Serbest-liberal bir aile ortamında büyüdügünü söyleyen iki kişi olmuştur. Bu minvalde, yetiştiriliş tarzı ile kadının eğitim seviyesi arasında bir ilişsi olduğu gözlenmiştir. Modern bir ailede yetiştiğini söyleyen kadınların çoğu üniversite mezunudur. Bu oran geleneksel ailelerde yetiştiğini söyleyenlerde daha düşük olup lise mezunu şeklinde tespit edilmiştir.

Araştırma sonuçları ailenin yanında eşlerin de kadınların girişimcilikte başarılı olmasında önemli faktörlerden biri olduğunu göstermektedir. Bu konuda iki katılımcının söyledikleri örnek verilebilir: "Benim ailemin en büyük desteği manevi olarak yanımda olmalarıydl. Eşim ve çocuklarım bu anlamda en büyük destekçilerimdirler. Biz burada 4 kişiyiz ve bir proje sonucunda buraya ortaklaşa aldiğımız kararlarla geldik. En büyük destekçimiz ailelerimiz oldu. Çünkü biz bu proje kapsamında Almanya'ya, Moskova'ya gittik. Aynı zamanda Türkiye'de birçok fuara katıldık, bu fuarlara katılırken kimseye gidebilir miyiz diye sormadan direkt biz gidiyoruz dedik ve katıldik. Manevi destek sonsuz ama maddi desteği biz çalışarak sağladık" (K39yaş-El Sanatları). Bir diğer katılımc1 "Ben eğitimci olduğum için iş hayatımı ailem de destekledi. 3 tane çocuğum var ve bu 3 çocuğu yapma cesaretini çocuklarımın eğitimleri süresince yanımda olacaklarını bilmemdi. En büyük destekçim eşim oldu, benim yokluğumu hissettirmedi. Bu açıdan birbirimizi tamamliyoruz, birimizden birimiz mutlaka çocuklarımızın yanlarında oluyor Bu açıdan benim için avantajdı" (K55yaş-okul müdürü) sözleriyle eşin desteğini vurgulamıştır.

Alınan cevaplardan yola çıkılarak girişimcilik cesareti gösteren kadınların bu kararı almalarında baba ya da eşin mesleğinin etkili olabileceği sonucuna varılmıştır. Araştırmada, katılımcıların annelerinin büyük ölçüde çalışmadığı ortaya çıkmıştır. Ancak, babası esnaf ya da serbest meslek erbabı olan kadınlar ile eşleri esnaf veya serbest meslek erbabı olan kadınların girişimcilik konusuna daha cesur yaklaştıkları anlaşılmaktadır. Bu durumu kadınlardan biri şu şekilde dile getirmişlerdir: "Ben zaten ticaret yapan bir aileden geliyorum, erkek kardeşim benim gibi girişimci. Yani biz aileden, çekirdekten ticaret donanımliyız. Ama benim şu anki şirketim aile işi değil ben ailemden farklı bir dalda iş yapıyorum" (K50yaş-konfeksiyon). Diğer bir katılımc1 "Babam da serbest meslek sahibiydi ve bana önemli etkisi oldu. Çalı̧̧ma hayatım mezun olduğumda devlet memurluğu şeklinde sinırlanmadı. Ben devlette çok kisa süre çalıştım, hayatımı devam ettirebilmek için mutlaka devlette bir işim olsun mantığılla büyümedim. Çünkü babam evin gelirini sağlayan tek kişiydi ve devletten o anlamda beklentimiz olmadl, kendi işimizi kendimiz kurduk" (K55yaş-okul müdürü) şeklindeki sözleriyle ebeveynlerinin girişimcilik deneyimleri kendilerinin bu yolda ilerlemelerine katkı sağladığı görülmektedir.

\section{II-Katılımcıların Girişimcilik Deneyimlerine Dair Bilgiler}

$\mathrm{Bu}$ başlık altında, öncelikle katılımcıların girişimciliği nasıl algıladığı-girişimcilikte önemli hangi faktörlerin olduğu vb. üzerinde durulmuş ardından bu sürecin aile yaşantılarına nasıl yansıdığ 1 irdelenmiştir. Ardından, kadın girişimci olmaya nasıl karar verdiği, hangi sektörde sürece 
dâhil olduğu, bu süreçte ne gibi sorunlarla karşılaştığı ve son olarak hedef ve beklentilerinin neler olduğu ortaya konmuştur.

\section{Katılımcıların Girişimcilik Algısı}

Araştırma kapsamında görüşülen kadınlara girişimcilikte hangi özelliklerin etkili olduğu hususunda bir soru yöneltilmiştir. Girişimci kadınlarda olması gereken karakteristik özelliklerin başında cesur olmak, kendi güçlerinin farkında olmak, liderlik vasfına sahip olmak, korkmadan risk alacak cesarete sahip olmak, maddi olanağa sahip ve çıkan zorluklara boyun eğmeyen bir yapıda olmak gelmektedir. Bu konuda iki katılımcının söyledikleri örnek verilebilir:

"Lider olmall, cesaretli olmall, öncelikle ben oldum diyebilmeli bir bilgi birikimine sahip olarak işe girişmeli. Çok fazla gözü kara cesaret çok da iyi bir şey değil. Altının sağlam ve dolu olmasl gerekir ve tabii ki maddi olanaklara sahip olmak lazım. Belli bir çevreye ve iyi bir ekibe sahip olunmall. Benim girişimcilikte etkili olan en önemli özelliğim ise liderlik diyebilirim. Kendime güvenmem ve altyapımım sağlam olması ve diş etkenler insanlardan aldiğım o olumlu tepkiler bulunduğum yere gelmemdeki diğer etkenlerdir." (K30-İçimar)

"En başta risk almayı göze alabilecek bir cesareti olmalıdır. Bunun dışında bulunduğu ortamı iyi idare edebilen, insanlara saygılı olan, insan ilişkilerinde sabırlı olması gereken bir insan olmalıdır. Yoksa iş hayatı o kişiyi çok fazla yıpratır ve mutlu etmez.” (K36yaş-Güzellik salonu).

Bunun dışında kadın girişimcilerin, çalışanları için adil olması, aile reisi gibi olması, dürüst ve örnek kişi olması, çalışanlarının yeri gelince önünü açabilmesi, ufkunu açabilmesi, insanlarla iletişim kurmasını bilmesi, düzgün çalışması, doğru insan olması, güler yüzlü olması, yaptığı işin arkasında durabilmesi, ikna yeteneğine sahip olması, soğukkanlı, sabırlı, çalışkan, takıntılı ve duygusal olmayan, eğitimli, girişken, konuşkan, lider, cesaretli, altyapısı kuvvetli, disiplinli, görsel algısı gelişmiş, araştırmacı ruhuna sahip, yurt içi yurt dışı piyasayı kontrol edebilen, yaratıcı fikirlere sahip olmak, hesabını iyi yapabilmek, risk almayı göze alabilecek nitelikte olması gereği ön plana çıkmıştır. Bu konuda iki kadın girişimcinin sözleri örnek verilebilir:

"Bence bütün çalışanları için adil olmalıdır. Zaten olmazsa olmaz olan şey elemanla duygudaşlık yapabilmektir yoksa olmuyor. Onun derdi ile dertlenmiyorsanız onun sevinci ile mutlu olmuyorsanız olmuyor. Bir aile ortamına sokamıyorsanı olmuyor o yüzden bir işletmeci aile reisi gibi olmalıdır. Dürüst olmalı, örnek olmalı, çalışanlarının yeri gelince önünü açmalıdır..." (K40yaş-Evyemekleri)

"Her şeyden önce düzgün, dürüst ve çalışkan olmalıdır. Ruhu geniş olmalı küçük şeylere takılmamalı eğitimli olmalı. Kendi giyimiyle konuşmasıyla tavrlyla bir bütünü oluşturmalı. Benim karakterim bu işte etkili oldu ben doğuştan girişimci olarak doğdum. Her zaman önden koştururdum zaten. Küçüklügümden itibaren ben kardeşlerimden onların arkadaşlarından her zaman farklıydım. Hayatımın hiçbir döneminde evde oturmadı." (K52-Konfeksiyon).

Kısaca, girişimci kadınlar için girişimci olmak o ruha sahip olmak, risk alabilmek, kendi ayakları üzerinde durabilmek, özgüven, iletişim, kendini tanımak, başka birine muhtaç olmamak, tatmin, istediğini elde etmek, her zaman yeni bir şeyler yapabilmek ve kendine olan güven anlamina gelmektedir.

\section{Kadın Girişimci Olmanın Aile Hayatına Yansımaları}

Kadınların iş hayatına atılması ile evdeki görev ve sorumlulukları hususunda ne gibi değişikliler olduğu önemli görülmüştür. Bu bağlamda kadınlara iş hayatına girmenin aile hayatına nasıl yansıdığı, iş hayatının aile hayatına olumlu ve ya olumsuz yönlerinin neler olduğuna dair sorular sorulmuştur. Girişimci kadınlar iş hayatına atıldıktan sonra aile hayatlarının olumsuz olarak etkilenmediğini aksine olumlu sonuçlar doğurduğunu ifade etmişlerdir. İş hayatında bir girişimci 
kadın olarak var olmalarının çocukları üzerinde cesaretlendirici etkiler bırakarak onlara farklı bakış açısını kazandırdıklarına inanmaktadırlar. İş hayatı içinde olmanın tek olumsuz tarafının çocukları ile yeterince vakit geçirememek olduğu düşüncesindedirler. Bu konuda üç katılımcının sözleri şu şekildedir:

"Ben evde çok sorumlulukları olan bir insan değilim, kayınvalidem ve görümcemle hep birlikte yaşıyoruz. O yüzden eve gittiğimde çocuklarıma zaman ayırabiliyorum. Yani çalışan bir annenin boşluğunu çocuklarım çok fazla yaşamıyorlar. Çünkü gündüz onlar okuldalar ben işteyim, akşam beraber oluyoruz." (K43yaş-evyemekleri)

"Aile hayatımda bir etkilenme olmadı ama kişilik olarak beni çok etkiledi. Daha özgüvenli bir birey oldum, daha rahat bir insan oldum. Kısacası kişiliğimi geliştirdim. Aile hayatına daha mantıklı ve güvenli bakmamı sağlad. Ben ailemi bu konuda onların beni etkilediklerinden daha fazla etkiledim. Kendime güvenim arttıkça aileme olan baklş açım da değişti. Kültürel anlamda onları fazla etkiledim" (K46yaş-Güzellik Salonu).

"Olumlu yansıdl. Farklı ve iyi işler yapıp bunları da ailem duyunca çok mutlu oldular, başarım onları mutlu etti. Şu an iş hayatı benim için çok yorucu çünkü çocuğum var ve belli bir yaştan sonra yorulmaya başliyorsunuz. Genel olarak düzenli bir hayatımın olması nedeniyle olumlu etkisi olduğunu düşünüyorum. "(K41yaş-Mobilya).

Diğer taraftan, evdeki iş paylaşımı hususunda ise eşlerinin anlayışı ile bu konuda sıkıntı yaşanmadığı dile getirilmiş̧tir. Araştırmada aile içerisinde sorumluluklanı paylaşan ve onları yaptığı işle destekleyen ve teşvik eden eşlerin önemi büyük görünmektedir.

\section{Katılımcıların İş Deneyimine/İşletmeye İlişkin Bilgiler}

Kadın girişimcilerin yarısı işyerlerini 1996 ile 2000 yılları arasında kurduklarını beyan etmiştir. Kadın girişimcilerin hepsi işlerinin başındadır. Dört kadın girişimci eşlerinin de yanlarında olduğunu, zaman zaman işletmedeki etkilerinin arttığını belirtmişlerdir. Eşlerinin maddi ve manevi desteğini aldıklarını vurgulamışlardır. İşletmelerin tamamına yakını mikro ölçeklidir. Girişimcilerin yaklaşık yarısı işyerlerini 'tek kişi işletmesi' şeklinde kurmuşlardır. Diğerleri ise 'limitet şirket' olarak kurulmuştur. Kadın girişimcilerin faaliyet konularına bakıldığında beşinin 'ticaret', kalanının ise 'hizmet' sektöründe iş kurdukları anlaşılmaktadır. Kadınlar genellikle cinsiyet rollerine uygun ve fazla sermaye gerektirmeyen ve geliri düşük olan işler yapmaktadırlar. İşletmelerdelfirmalardaki çalışan sayıları ise en fazla 24 ile okul bünyesinde en az iki ile el sanatları işletmesinde çalışmaktadır. İşletme veya firmaların içinde faaliyet gösterdikleri alanlar ise ev yemekleri-tatlıları, eğitim, konfeksiyon (hazır giyim), güzellik salonu, iç mimarlık, mobilya ve aksesuar, dekorasyon ve aydınlatma, el sanatları (kazaziye-takı vb.) olarak farklılık göstermektedir.

Görüşülen kadınları kurmuş olduğu işletmelerin kurulduğu günden bu yana gelir ve kar durumlarında artışlar olduğunu ifade etmişlerdir. İşçi sayısındaki değişmelere bakıldığında, kurulduğu günden itibaren işçi sayısı aynı kalan iki tane işletme bulunmaktadır. Diğer işletmelerin işçi sayısı gelir durumuna göre artış göstermiştir. Bu konuda iki katılımcının söyledikleri örnek verilebilir: "Kurulduğu gün üç kişi başladık hala ü̧̧ kişi devam ediyoruz. Hiçbir işçi alımı yapılmadl." (K39yaş-El Sanatları); bir diğeri "Yaz sezonunda özellikle çok yoğun oluyoruz. Ama işinizi ve kendinizi hep ona göre ayarllyorsunuz. Tek bir mekânla başladık daha sonra tabii ki işçi sayısında gelirde değişmeler bu yönde de artışlar oldu."(K57-Pastane)

\section{Kadınların Girişimcilikte Karşılaştığı Sorunlar}

Kadın girişimcilerin işletmelerinin faaliyetleri sırasında karşılaştıkları sorunlar, başlangıçta ve ilerleyen süreçlerde karşılaşılan sorunlar olmak üzere iki grupta sunulabilir. Başlangıçta aile ilgili sorunlar (çocuklar-aile desteğini kazanma vb.) ile ekonomik sorunların yaşandığı genelde tüm katılımcılar tarafından dile getirilmiştir. Bir kadın girişimci şu sözleriyle bu durumu özetler: " $B u$ işe ilk başlardan çocuklarımın kü̧̈ük olması, eşimin bu tarz bir şeyle uğraşmamı istememesi gibi 
sorunlarım vardı. Eşim istemiyordu ama evimin mutfă̆ını kullandım, işe gidip gelene kadar işlerimi hallediyordum. Ev hanımı olarak işe başladım, aradaki dengeleri kurmak çok zordu. Ama şu an çok şükür sistem oturdu" (K57-Pastane.). İşyerinin açılması borç alınarak yapıldığında ise durumun daha riskli olduğu gözlenmiştir. Bir katılımcı, "maddi güçlüklerle karşılaşstım çünkü işe başlarken hiç birikimim yoktu. Daha önceden olan eczanemi devrederken belli bir miktar para vardı, onunla başladım. Sonrasında yaptı̆̆ım satışlarla kazanç sağladım. Risk alarak ve borçla başladım" (41yaş-Mobilya) şeklindeki sözleriyle karşılaştığı sorunu dile getirmiştir. Ayrıca, ekonomik krizler sürecinde durumun daha da riskli ve belirsiz olduğu, bunun da geleceğe ilişkin karar almayı zorlaştırdığı belirtilmiştir. Bunun yanı sıra, dükkânı ilk açtıkları zaman günlerce boş oturduklarını, kirayı ödemekte zorlandığını belirtenler olmuştur. Devlete ödenen vergilerin de çok fazla olduğu sıkça dile getirilmiştir. Bu arada mekân bulma konusundaki sıkıntılar, yer ve kira ücretlerinin yüksek oluşu da dile getirilmiştir.

Diğer taraftan, ilk başlarda iş tecrübesi olmayan kadınlar bu süreçte zorlandıklarını ancak zamanla işe ve piyasaya hâkim olduklarını belirtmişlerdir. İki kadın girişimcinin söyledikleri buna örnek verilebilir

"Eskiden anlamakta güçlük çektiğim noktaları şu an çok hızlı bir şekilde anlayabiliyorum. Eleman ve ürünler konusunda ustalaştım diyebilirim. Laz böreği biraz farklı ve bilinmedik bir tat olduğu için insanların ilgisini çekmişti. Beğeniler artarak talepler de arttı derken Trabzon küçük bir yer olduğu için yayıldı ve ismim bu şekilde duyuldu (K57-Pastane.).

"Gün geçtikçe birçok insanın tercih ettiği ve mezun olduğu bir alandır. Bence eksik donanımlarla yetiştirilip piyasaya girebileceklerine iş ve faaliyet gösterebileceklerine inanan insanlardan oluşuyor genellikle. Ama bu insanlar uygulamaya geldikleri zaman asıl piyasaya işin içine girdikleri zaman çuvallyyorlar. Bu konuda isim vermeyim bazı özel üniversitelerden çok kolay mezun olarak hiçbir şantiye eğitimi almadan altyap oluşmadan kolaylıkla mezun olabiliyorlar. Dolayısıla piyasadaki iş kalitesini, müş̧eriyi iyi analiz etmesi gerekiyor. Doğru kişilerle doğru şekilde çalışmak çok önemlidir. Dolayısılla bizim alanımızda faaliyet gösteren özel firmalar çoğaldı. Bunlar iş yapıyor mu derseniz aldı̆̆ım piyasa duyumlarına göre birçoğu yetersiz. Dolayıslyla sizin bir farkınızın olması gerekiyor. Bu farkta bilgi birikimiyle yaptı̆̆ınız işlerle ve referanslarla iyi projelerle sizi ayakta tutuyor."(K30yaş-iç mimar).

Müşteri memnuniyetine dayalı işlerde özellikle hizmet sektöründeki kadın girişimciler ise işlerin sürdürülebilirliği ile hizmetin sunumu ve kalitesi arasında bir bağ olduğunu ve bununda işlerini olumlu ya da olumsuz yönde etkilediklerini söylemişlerdir. Bir katılımcı bu durumu şu şekilde dile getirir: "Bu sektörde insanları mutlu etmek oldukça güç, çünkü herkesin ayrı bir fikri var. Şu anda da insanlarla uğraşmak, onları memnun etmek gibi zorluklarla karşılaşlyorum. Insanları mutlu etmek gerekiyor çünkü mutlu olan insan geri gelir öteki türlü müşteri kaybedersin. Buraya kadınların \% 90'ı kafasındaki şeyi yaptırmak için geliyor, işte bunu bulmak benim işim ve bu oldukça zor. Yani beni en çok zorlayan insan ilişkileri oldu" (46yaş-güzellik salonu).

Sektördeki rekabetin de olumlu ya da olumsuz sonuçlar doğurduğu ifade edilmiştir. Küçük işletmelerin güçlü ve büyük işletmeler karşısında tutunmakta zorlandıkları vurgulanmıştır.

"Biz bu işe başladığımızda bu iş alanındaki diğer insanlardan bizi yıldırmak isteyen bir sürü kişi vardı. Küçük bir parça olan bileklik kordonunun bile nereden alındığını söylemediler. Ama ben hırs yaptım ve İstanbul'a giderek bir gün boyunca kuzenimle birlikte bu parçayı buldum. Aynı şekilde çeşitli diğer parçaların da nereden alındı̆̆ını bize söylemediler, o parçaları da Istanbul'dan kendi aramalarımla buldum. Biz 3 ortak kadın olarak buraya başladık, para bizim için ikinci planda. Amacımız başarllı olmak ve biz bunu yapacağız" (39yaş-elsanatlarl).

"En büyük güçlüğü ülkenin geçirmiş olduğu ekonomik krizler sirasında yaşadım. Onun dışında rekabet de etkili oldu, bebek giyim sektöründe erkeklerin açmış olduğu firmalar daha fazla yoğunlukta. Bu durum da ortaya erkek egemenliğini çıkarıyor" (K52yaş-tekstil). 
"Mobilya sektörü farklllıklar gösteren bir sektör, bu sektörde çalışıp iyi şeyler yapmak için bir araya gelemezsiniz. Satış politikaları yanlış olan firmalar var. Esnaf arkadaşını ezerek müşteriyi mutlu etmek ya da ürünün değerini düşürerek bunu yapmak yanlıştır. Bu sektörde çalışanların çoğu belli bir eğitimden ve tecrübeden yoksunlar" (K4lyaş-mobilya).

Kısaca, kadının çalışma yaşamında karşı karşıya bulunduğu sorunların temelinde, toplumun ekonomik, sosyal ve kültürel yapısındaki bazı aksaklıklar yatmaktadır. Kadınların bu sorunların üstesinden gelmesi zamanla, deneyimle ve süreç içinde yol almak suretiyle gerçekleştiği tespit edilmiştir.

\section{Katılımcıların Hedef ve Beklentileri}

Katılımcıların daha fazla kurum ile işbirliği kurma ve iletişim ağlarından yararlanmaları gelecekteki ihtiyaçları açısından önem arz ediyor. Kadın girişimcilerin en fazla ihtiyaç duydukları konu finansal destek olarak gözüküyor. Çoğu işlerinin bu şekilde gitmelerinden memnunlar, daha fazla büyümek gibi planlarının olmadığı dile getirilmiştir. Bir kadın girişimci "Güzellik salonumu açtığım ilk zamanlardaki kazancımla şu anki arasında bayağı bir uçurum var. İlk zamanlar kendimi çevirmekten başka hiçbir şey düşünmüyordum ama şimdi artılara geçmeyi planlıyorum” (46yaş-güzelliksalonu) şeklindeki sözleriyle hedefini kar payını yükseltmek" olarak belirtmiştir. Son olarak devletten düşük faizli iş geliştirme kredisi vergi indirimi, teşvik gibi kolaylıkların sağlanması, iş yeri kiralarına destek, bürokratik işlemlerin azaltılması, sorunların çözülmesi hususunda beklentiler dile getirilmiştir.

\section{Sonuç ve Öneriler}

Ülkemizde kadınlarımızın iş gücüne katılımları halen arzu edilen bir seviyede değildir. $\mathrm{Bu}$ araştırma kadın girişimcileri odağına alarak Trabzon özelinde girişimci kadınların varlığına dikkat çekerek onların girişimcilik deneyimlerini ortaya koymak üzere tasarlanmıştır. Alanlarında Trabzon'a ilkleri yaşatmış ya da değişimin öncüsü olmuş cesaretli bir o kadar da azimli kadınlar araştırma sürecine dâhil edilmeye çalışılmıştır. Görüşülen kadınların gerçekten bu işe inanmış, başarı odaklı çalışan, azimli, özgüvenli ve en çokta kendi ayakları üzerinde durmaktan keyif alan kadınlar olduğu tespit edilmiştir.

Araştırmaya katılan 14 kadın girişimci, 30 ile 57 yaş aralığındadır. Yıllardır çalışan kadın girişimciler kurdukları işletmeyi/firmayı devretmeyi, çocuklarına bırakmayı ya da emekli olmayı düşünürken diğerleri ayrılma gibi planlarının olmadığını onlar olmadan işletmenin ilerlemeyeceğini düşünmektedirler. Kadınların, insanlarla birebir ilişkisini gerektiren fonksiyonlarda etkili; mali ve resmi işlerde ise daha az etkili olduğu söylenebilir. Kadın girişimcinin eğitim seviyesi yükseldikçe işletme fonksiyonlarındaki etkisi artmaktadır. Diğer taraftan; üniversite mezunu kadın girişimcilerin yanında çalışan işçilerin işletme fonksiyonlarına etkisi, diğerlerine kıyasla daha fazladır. $\mathrm{Bu}$ durum, üniversite mezunu kadın girişimcilerin daha demokratik ve katılımcı bir yönetim anlayışına sahip oldukları şeklinde yorumlanabilir. Liberal ve modern bir ortamda yetişen kadın girişimcinin geleneksel ve koruyucu ortamlarda yetişen hemcinslerine kıyasla işletme fonksiyonlarında daha etkin olduğu gözlenmiştir. Geçmişte annesi çalışan veya halen çalışmakta olan kadınlar, işletme fonksiyonlarında diğerlerine kıyasla daha etkilidir. Bu durum, çalışan annelerin çocuklarını daha öz güvenli yetiştirdikleri şeklinde yorumlanabilir. Eşin işe ortak olduğu durumlarda, işletmede kocanın etkisi artmakta, kadının etkisi azalmaktadır. Bu durum, ortaklık durumunda kocanın kararlarda daha belirleyici olduğunu anlatmaktadır. Kadınlarının çoğunun işletme fonksiyonlarına etkisi olduğu, işin başında olduğu, işçisi ve aile üyelerinden birileriyle çalıştı̆̆ 1 tespit edilmiştir. Eş ya da baba daha çok finansman sağlayan, mali ve resmi işlerde yardımcı olan kişidir. Bunun dışında, araştırma sonucunda cesaretli olmaya ihtiyaçları olduğu anlaşılmıştır. Cesaretli bireyler olabilmek için yetiştirilme tarzı ve anne-baba mesleklerinin hayata bakış açısını etkilediği görülmüştür. Girişimcilikte en büyük etkenin kadınların gerçekten 
başarabileceklerinin farkında olması gerçeğidir. Bu süreçte, eş ve ailelerinin onların her zaman en büyük destekçileri olduğu fark edilmiştir

Cinsiyet rolleri zamanla, toplumdan topluma fark etse de hiçbir zaman değişmeyen tarafi cinsiyet kavramının temelindeki erkekler üzerindeki pozitif ayrımcılık olmuştur. Kadın girişimcilerin sayısının düşük oluşu ve daha çok mikro ölçekli işletmelerde yoğunlaşması bunun bir göstergesidir. Geleneksel olarak toplum içindeki oluşan cinsiyet rolleri kadını erkeğe bağımlı ve bağlı kılmaktadır. Eşlerin özellikle maddi ve manevi desteğine duyulan ihtiyaç açığa çıkmıştır. Cinsiyetler arasında toplumsal rol ayrımı kesin sınırlarla belirlenirken, kadın da ekonomik yönden erkeğe bağlı olmuştur. Kadın ekonomik karşılığı bulunmayan "ev işi” ve "çocuk bakımı" gibi günlük faaliyetleri üstlenirken, erkek ev dişında çalışarak evin geçimini sağlayan kişi konumuna gelmiştir. Bu durum, erkeğin ekonomik ilerlemenin temel faktörü konumunda olmasına neden olmuştur. Bu açıdan erkek, kendisine atfedilen bu toplumsal rol ile ekonomik olarak üretken olup, toplumsal bir değer elde etmiştir. Kadın ise, ekonomik anlamda erkeğe bağımlı olmanın yanında, yaptığı faaliyetlerin ekonomik bir değerinin olmamasından dolayı ikincil konuma düşmüştür. Ancak, hâlihazırda kadının çalışma hayatına giderek daha fazla sayıda katılması ile bu durum farklılaşmıştır (İşler, 2004:75). Kadın her ne kadar ev dışında ücretli veya ücretsiz aile işçisi olarak çalışması durumunda geleneksel rollerinden biraz uzaklaşmış olsa da, çoğunlukla elde ettiği yeni rollerle beraber, devam eden toplumsal rollerini de yerine getirmek durumunda kalmıştır.

Feminist iktisat kuramı bağlamında, cinsiyet faktörünün oluşturduğu rol tutumlarının kadın girişimciler için sektör seçiminde etkili olduğu gözlenmiştir. Zira kadınların kurduğu işletmeler toplumsal rollerine uygun olarak yemek-tatlı yapımı, pastane, cafe işletmeciliği, küçük ölçekte mağaza işletmeciliği vb. kendini göstermiştir. Firmaların çoğu finansal açıdan çok fazla bir yük getirmektedir. Bunun yanında kadın her ne kadar ev dışında ücretli veya ücretsiz aile işçisi olarak çalışması durumunda geleneksel rollerinden biraz uzaklaştırmış olsa da, çoğunlukla kadın elde ettiği yeni rollerle beraber, devam eden toplumsal rollerini de yerine getirmek durumunda kalmıştır. Kadınların ev içi rollerinde özellikle annelik rolleriyle birlikte giriştikleri sektördeki işlerin birlikte yürütüldüğü gözlenmiştir. Ayrıca, sermaye edinimindeki zorluk, düşük eğitim düzeyi ve geleneksel doku kadının koca ve aile bağımlılığını artıran unsurlar olarak ortaya çıkmıştır. Son olarak, bazı kadınların kendilerini geliştirmek adına etkinliklerde bulundukları, bazı kadınların ise kendilerini geliştirmek için bir uğraş vermedikleri görülmüş̧ür. Kadınların eğitim amaçlı faaliyetlere katılımlarının genellikle düşük olduğu, boş zamanlarında kendilerini geliştirmeye yönelik bir çaba içinde olmadıkları izlenimi doğmuştur. Bu sonuçlardan hareketle geliştirilen öneriler şunlardır:

> Yapılan araştırmada kadınların eğitim düzeyleri yükseldikçe işletme fonksiyonlarına ilişkin karar ve yürütmeye olan etkisinin artmakta olduğu görülmüştür. Dolayısıyla, kadınların eğitim düzeylerinin artırılmasına ilişkin önlemlerin alınmasında fayda vardır.

$>$ Rekabetle başa çıkabilmeleri adına, kadınların kendi aralarında örgütlenmeleri, sorun çözmeye ilişkin bilgi ve fikir alışverişi açısından büyük yararlar sağlayabilir.

$>$ Rekabetle başa çıkabilmek ve piyasada sürdürülebilirliği sağlayabilmek amacıyla düşük faizli iş geliştirme kredisi vergi indirimi, teşvik gibi kolaylıkların sağlanması, iş yeri kiralarına destek, bürokratik işlemlerin azaltılması konusunda yardımlar yapılması ya da arttırılması kadını destekleme ve cesaretlendirmede etkili olabilir.

> Kadınlar, bilgi ve becerilerini geliştirmede istekli olmalıdırlar. Sektördeki gelişmeleri yakından takip edebilmeleri amacıyla bilgi portalleri ya da platformları oluşturulabilir.

> Kadınların farklı beceriler ve meslekler edinmesini engelleyen cinsiyete dayalı iş bölümü, aile, eğitim kurumları ve medya yoluyla iyice pekiştirilmektedir. Bunun değişmesine yönelik tüm toplumu bilinçlendirme programları düzenlenmelidir. $\mathrm{Bu}$ amaçla, eğitim kurumları ve medyadan yararlanılması önemlidir. 


\section{Kaynakça}

Avşar, G. (2017). Kadın girişimcilerin karşılaştıkları sorunların tespiti ve bu sorunların kadın girişimciler üzerindeki etkilerinin incelenmesi: Adana ili örneği. Yayımlanmamış doktora tezi, Çağ Üniversitesi.

Başak, S. (2013). Toplumsal Cinsiyet. Sosyolojiye Giriş, Ed. İhsan Çapcioğlu ve Hayati Beşirli. Ankara: Grafiker Yayınları.

Cici, E.N. (2013). Kadınların girişimcilik yolunda karşılaştıkları sorunların öz girişimcilik yetenekleri üzerindeki etkisi: Konya ilinde bir araștırma. Yayımlanmamış yüksek lisans tezi, Selçuk Üniversitesi.

Çakıcı, A. (2003). Mersin'deki kadın girişimcilerin iş kurma öyküsü ve iş kuracak kadınlara öneriler, 11.Ulusal Yönetim ve Organizasyon Kongresi, Afyon Kocatepe Üniversitesi.

Çelebi, N. (1993). Kadın girişimciliğini özendirme ve destekleme konusunda politikalar. Kadını girişimciliğe özendirme ve destekleme paneli. Bildiriler ve tartışmalar.(Ed: Aypar Altınel). Ankara: Devlet Bakanlığı Kadın ve Sosyal Hizmetler Müsteşarlığı Kadının Statüsü ve Sorunları Genel Müdürlüğü. Eğitim Serisi, Yayın No:74

Çelik G.M. (2018). Kadın girişimcilerin karşılaştıkları sorunlar ve çözüm önerileri-TR71 düzey 2. bölgesi üzerine bir uygulama. Yayımlanmamış doktora tezi, Dicle Üniversitesi.

Çetin, A., Şentürk, M. ve Alacalar, A., (2015), "Mesleki İlgi Alanı ve Kişisel Ahlak Felsefesinin Girişimciliğe Yönelik Tutum ve Girişimcilik Niyetine Etkisi: Üniversite Öğrencileri Üzerine Bir Araştırma”. AIBBÜ Sosyal Bilimler Enstitüsü Dergisi, 15(2), 23-55.

Çulcu, A. G. (2009). Türkiye'de girişimci kadınlar: birikim, değişim ve kadınlık halleri. Yayımlanmamış yüksek lisans tezi, Marmara Üniversitesi.

Demirbilek, S. (2007). "Cinsiyet ayrımcılı̆̆ının sosyolojik açıdan incelenmesi”. Finans Politik ve Ekonomik Yorumlar Dergisi, 44 (51).

Demircioğlu, Z.(2016). Girişimcilik kadınlar için bir sosyal hareketlilik aracı olabilir mi? Eskişehir'de kendi işini kuran kadınlar üzerine bir değerlendirme. Sosyoloji Konferansları, (54):143-166.

Duman, L., Bedük, A., Köylüoğlu, A.S. ve Ay, K., (2015). Entrepreneurship culture at smes: a case study in Konya", Procedia-Social and Behavioral Sciences, (207):492-501. https://doi.org/10.1016/j.sbspro.2015.10.119

Ecevit, Y. (1993). Kadın girişimciliğinin yaygınlaşmasına yönelik bir model önerisi. Kadını Girişimciliğe Özendirme ve Destekleme Paneli. Ankara: Devlet Bakanlığı Kadın ve Sosyal Hizmetler Müsteşarlığı Kadının Statüsü ve Sorunları Genel Müdürlüğü. https://doi.org/10.21798/kadem.2016119799

Ecevit, Y. (2007). Türkiye'de kadın girişimciliğine eleştirel bir yaklaşım. Ankara: Uluslararası Çalışma Ofisi (ILO).

Eroğlu, Ö. ve İşler, R. (2004). İktisat düşüncesinde kadının konumu ve feminist iktisat. Maliye Araştırma Merkezi Konferansları, 46, 54-81.

Gözübüyük Tamer, M. (2016). "Kayıtdışı istihdamın çalışanları: ev hizmetlisi kadınlar”. Turkish Studies, International Periodical for the Languages, Literature and History of Turkish or Turkic, (11): 213-232. https://doi.org/10.7827/turkishstudies.9682 
Gözübüyük Tamer, M. (2016). Toplumsal cinsiyet eşitliğinin temsilinde örnek bir bilim insanı: Trabzonlu Mualla Eyüpoğlu Anhegger. I. Uluslararası Kanuni Sultan Süleyman Seтровуити Bildiri Kitabl, Trabzon.670-682

Gupta, A. and Muita, S.R. (2013). Relationship between entrepreneurial personality, performance, job satisfaction and operations strategy: An empirical examination. International Journal of Business and Management, 8(2), 86-95. https://doi.org/10.5539/ijbm.v8n2p86

Gürol, A. (2000). Türkiye'de kadın girişimci ve küçük işletmesi: firsatlar, sorunları, beklentiler ve öneriler. Ankara: Atılım Üniversitesi Yayını-2.

Işık, F.(2015). Kadınların ekonomideki yeri ve önemi. T.C. Bilim, Sanayi ve Teknoloji Bakanlığı Verimlilik Genel Müdürlüğü Yayını, Cilt:27, (315):1-32

İşler, R. (2004). İktisatta feminizm ve Türkiye ekonomisinde kadının rolü. Yayımlanmamış yüksek lisans tezi, Süleyman Demirel Üniversitesi.

Kahraman, Ü. G. (2017). Toplumsal kültürün kadın girişimci türleri üzerine etkisi: Batı Akdeniz kadın girişimcileri üzerine bir araştırma. Yayımlanmamış doktora tezi, Mehmet Akif Ersoy Üniversitesi. https://doi.org/10.20875/makusobed.637274

Kalaycı, İ. (2017). "Feminist iktisat: toplumsal cinsiyet eşitliğine seçenek bir bakış". ASEAD, (4): 533-542.

Kutanis, R. Ö. (2003). “Girişimcilikte cinsiyet faktörü: kadın girişimciler”. 11.Ulusal Yönetim ve Organizasyon Kongresi, Afyon Kocatepe Üniversitesi.

Kutanis, R.Ö. ve Alpaslan, S. (2006). “Girişimci ve yönetici kadınların profilleri farklı mıdır?”. Afyon Kocatepe Üniversitesi İ.̇.B.F. Dergisi, Cilt VIII, Say1 2.

Mazgal, S. (2013). Girişimciliğin bir kariyer olarak tercih edilmesinde dışsal faktörlerin belirlenmesine yönelik bir araştırma. Yayımlanmamış yüksek lisans tezi, Sakarya Üniversitesi.

Mert, İ.S. (2017). "Ev hanımlarının girişimciliği: Gaziantep ilinde nitel bir araştırma". Bingöl Üniversitesi Sosyal Bilimler Enstitüsü Dergisi (7):63-78. https://doi.org/10.29029/busbed.341991

Orkunoğlu, Şahin, I.F. ve Yılmaz Furtuna, E. (2017). "Feminist İktisat Teorisi Bağlamında Cinsiyete Duyarlı Bütçeleme". Türkiye Barolar Birliği Dergisi, Özel Sayı:30, 441-472

Ömer E. ve İşler, R. (2004). "İktisat düşüncesinde kadının konumu ve feminist iktisat”. İstanbul Üniversitesi İktisat Fakültesi Maliye Araştırma Merkezi Konferanslart, 46. Seri. https://doi.org/10.1501/sbfder_0000000544

Ören, K. ve Biçkes, M. (2011). "Kişilik özelliklerinin girişimcilik potansiyeli üzerindeki etkileri: Nevşehir'deki yükseköğrenim öğrencileri üzerinde yapılan bir araştırma". Süleyman Demirel Üniversitesi İktisadi ve İdari Bilimler Fakültesi Dergisi, 16 (3), 67-86. https://doi.org/10.30798/makuiibf.349660

Örümcü, A. N. (2015). Girişimci kadınların başarı ve güçlenme öykülerinin toplumsal cinsiyet analizi: Batı Akdeniz örneği. Yayımlanmamış yüksek lisans tezi, Süleyman Demirel Üniversitesi.

Özgüner, M. (2015). “Girişimcilik tipleri ve kişilik tipleri ilişkisi üzerine bir inceleme”. Route Educational and Social Science Journal, 2 (1): 148-160. https://doi.org/10.17121/ressjournal.228 
Özkul, G. ve Dulupçu, M.A. (2007). "Kişisel gelişimin girişimci tipleri üzerine etkisi: AntalyaIsparta illerinde bir inceleme". Girişimcilik ve Kalkınma Dergisi, 2 (2), 67-92. https://doi.org/10.17121/ressjournal.228

Öztürk, İ. (2008). Girişimcilik Raporu: Rapor I. İstanbul: İGİAD Yayınları.

Punch, K.F. (2005). Sosyal araştırmalara giriş. Nicel ve nitel yaklaşımlar. Çev.Zeynep Akyüz, Dursun Bayrak, H. Bader Arslan, Ankara: Siyasal Yayınevi.

Soysal, A. (2010). "Kadın girişimcilerin özellikleri, karşılaştıkları sorunlar ve iş kuracak kadınlara öneriler: Kahramanmaraş ilinde bir araştırma". Eskişehir Osmangazi Üniversitesi İ̈BF Dergisi, (5): 71-95.

Strober, M. H. (1994). "Rethinking economics through a feminist lens, papers and proceedings of the hundred and sixth annual meeting of the American economic". The American Economic Review, 84(2), 143-147.

TÜİK (2019) Hanehalkı işgücü araştırması sonuçları-2018

Yağcı, F. ve Bener, Ö. (2005). "Girişimci kadınların demografik ve genel karakteristikleri ile kadınları girişimciliğe motive eden faktörler”. Bilig, (33): 85-100.

Yalınkaya, O. (2018). Çalışma hayatı ve kadın. https://www.academia.edu/ Erişim Tarihi 01.08.2018

Yıldırım, A. ve Şimşek, H. (2016). Sosyal Bilimlerde Nitel Araştırma Yöntemleri. 10. Baskı. Ankara: Seçkin Yayınevi. 